Journal of Law \& Social Studies (JLSS)

Volume 3, Issue 1, pp 28-37

www.advancelrf.org

\title{
Gender Diversity in Corporate Boards: A Comparative Study of Pakistan and Norway
}

\author{
Tayyaba Noor Asghar \\ Advocate High Court \\ Email: tayyabanoor506@gmail.com
}

\begin{abstract}
With the increased attention given to corporate governance, there has been more focus on the lack of gender diversity in corporate boards. Within the context of corporate governance, this research focuses on the gender diversity in the boardrooms and to evaluate how the percentage of female directors on a company's board affects the firm's performance. For this purpose, Gender diversity in both Norway and in the Pakistan are studied, but this study more focuses on the Pakistan's board gender diversity, legislations, implementation and its impact on company's performance, this study also focuses on Norwegian experience and the impact of the Norwegian gender diversity rule. This study is conducted by a qualitative research and a socio-legal research methodology due to library based and its mixed nature of being legal and corporate respectively. This study is also based on primary as well as secondary sources. The results of this study show that there is observable performance benefit to adding more females to the board of directors. Companies found a significant and positive relationship between the percentage of women on the board and performance. These results suggest that if Pakistan decides to adopt strong legislation for corporations in relation to gender diversity and implement them; it will observe significant improvement in firm performance.
\end{abstract}

Key words: Gender diversity, Corporate boards, Pakistan and Norway

\section{Introduction}

Gender diversity is a central subject in the management of major companies in Europe and worldwide. This is one of the most emphasized forms of diversity in the boardroom. Corporate boards have mostly male dominancy historically. This practice has been challenged when many companies known about the benefits of diversity within the firm and boardroom. Women sit in the boardroom with their males and carry a different management and perspective style with them.

Modern corporations faced gender diversity as most significant among the various board diversity characteristics. It is a matter of interest not only to literature about diversity, but also to political and social problems. Even though there are several females in boardroom but still there's ongoing struggle for having more females on the top-level positions is a current global problem. Several nations have started implementing initiatives for promoting female's representation on corporate boards.

Due to lack of literature in the extent of corporate governance in Pakistan's corporate boards, laws are insufficient regarding gender diversity in corporate boards and an inappropriate application and implementation. It shows that regulators like the Pakistan Institute of Corporate Governance (PICG) and the Securities and Exchange Commission of Pakistan (SECP) have unsuccessful to implement the law in their true spirit and to increase public awareness and recognition of the benefits of gender diversity in corporate boards by the Commission to date. A lack of interest or ignorance by government and companies on this topic is the main reason for this inappropriate compliance of gender diversity in corporate boards.

The purpose of this research is going to be trying thorough research on the benefits and drawbacks of gender diversity on corporate boards, their application, implementation and therefore the result. For that purpose, the samples of 
Pakistan and Norway systems are going to be used. Norway is that the greatest sample of getting well well-known system of gender diversity on corporate boards of corporate governance codes. Compliance with the codes of corporate governance of corporate boards is one of the company's listing criteria in Pakistan, so companies are sure to obey those guidelines. Both countries have codes much like the international codes of corporate governance and the corporate governance codes are practised by both countries. The distinction lies in the momentum as the codes in both countries are accepted, implemented and enforced.

\section{Norwegian Gender Diversity}

This quota was set at 40 percent in 2003; the first country was Norway to put in legislation for women's quotas on the boards. Some of the results have been examined in recent studies. Recent studies show that Norway's quota law did not, as businesses feared, contribute to hiring unqualified directors in 2014. Researchers found that women's skills for such positions have subsequently increased. Researchers have found that quotas have not yet eliminated gender discrimination in Norwegian businesses and reversed the disparity between men and women.

In the boards of public corporations, Norway adopted high women's quotas. In 1980 Country adopted the first quota of gender in some sectors and extended it to at least 40 percent of women in boards of public limited firms, multinationals and state-owned companies in 2003.

Gender quotas in Norway worked with penalties only. Just 17 percent of the members of the board were female in 2005. To achieve the target quotas, restrictions, including the threat to businesses, were tightened and introduced in 2005 , and rapid change occurred. In 2008, the target of 40 percent was achieved. In 2008, quota coverage was extended to corporate enterprises and to municipal enterprises in 2009.

\subsection{Strategy of Norwegian Gender Quota Rule}

In 2002, Norway introduced first compulsory corporate gender quota rule in the world, Minister of trade and industry, Ansgar Gabrielson, made it obligatory for the state companies to have at least 40 percent of the female's directors on boards. In an interview the issue of unequal gender representation on boards has been the subject of discussion since long time was a carefully designed strategy. The fact that the ratio of women directors in the corporate boards of corporations of Norway increased from 4 to 6 percent in 20 years from 1992 despite voluntary efforts is not a choice.

The strategy succeeded and on 1 January 2006 new section 6-11a of the Public Limited Liability Companies Act of Norway was put into effect. The company's choice was indirectly its entry into force. This legislative initiative took an inventive approach: the law laid down in 2003 stipulated that only if the corporations did not have 40 percent representation by women in their boards would the regulation be in effect by 1 July 2005 .

Despite complaints that companies would work this out themselves if left alone, a complete span of two years was not enough to deliver the numbers they needed. Just 15.5 percent of women were in public corporations' boards and up to 80 public businesses by July 2005 did not cross 40 percent of either gender. Therefore, the law came into effect for two more years.

Since the latest gender-neutral law meant that women had to be hired over a two-year period because of the current male domination of businesses. Many public corporations have reintegrated the law on gender diversity into a reality like private companies. Other aspects appear to have been ignored, justifying re-incorporations.

\subsection{Aim of Norwegian Gender Diversity Rule}

All public limited liability companies in Norway registered under section 6-11a in all Norwegian company registers. Section 6-11a of the gender equality rule does not apply to private limited undertakings. Private firms have been excluded because their shareholdings are less dispersed than public firms, and because Norwegian companies are mostly family-owned, and shareholders are also board members.

This legislative change was central to better corporate governance. The primary goal of this section 6-11a was to employ more females in the executive boards for company success and competitiveness. The legislative framework was chosen for the compulsory quota rule rather than agreeing with or clarifying the requirements or target rules under which businesses could report their progress reports.

\subsection{The Facts of the Norwegian Gender Diversity Rule}


A certain number of genders selected by the BODs shall be represented in public corporations by means of section 611a. Section 6-11a is based on the gender-neutral text; however, it demonstrates that male dominance is highlighted in public boardrooms.

It is compulsory to have only each gender represented in the companies having small boards; while the large companies require 40 percent of each gender. The Norwegian rule is best known for this latter requirement. The rule is specified in section 6-11a is mentioned below:

"If the board of directors has two or three members, both genders shall be represented. If the board of directors has four or five members, each gender shall be represented with at least two members. If the board of directors has six to eight members, each gender shall be represented with at least three members. If the board of directors has nine members, each gender shall be represented with at least four members, and if the board of directors has more than nine members, each gender shall be represented with at least 40 percent of the board of directors."

Section 6-11a requires both the managers as well as the alternate managers to be chosen in compliance with the rules on co-determination at general meetings or employees by shareholders.

In the minds of many people, both scepticism and criticism were previewed as Section 6-11a was so fresh. Many legal scholars from Norway and Some of the confusion surrounding section 6-11a enforcement were commented by other commentators.

\subsection{Consequence of Non-Compliance of Norwegian Gender Diversity Rule}

Legal authority responsible for the ensuring of boards acting upon the section 6-11a is the Norwegian Register of the Business Enterprises. Firm acting in violation of section 6-11a is punishable by ordinary law.

The refusal of registration in the Business Enterprise Registration (RBE) is a significant form of sanction, which will have a major impact on company operation. Dissolution of the existing company is the most severe sanction. An actual dissolution will occur when the company has many warnings and opportunities to set up a legal board.

It is requirement or compulsion for the companies to have at least one female in their corporate boards by 1st January 2008. By the end of 2007 the Norwegian RBE had listed 483 public corporations. By January 7, 2008, 90 percent of the boards were in accordance with section 6-11a. Many companies have a necessary representation of women in their boards a couple of months in 2008. Only a few were to give notices on not complying to the section 6-11a. If they do not comply to the rule, then no companies had to be punished for infringing the rule.

The dissolution of a firm, as companies not operating under section 6-11a, was criticised at the time the legislation was passed. However, preparatory work emphasises the most effective and appropriate penalty is dissolution. The sanction is lines that deal with fundamental requirements are breached including requirement in sending the accounts. The compulsory quota rule of Norway must be taken seriously as core corporate law is to be enforced. This also demonstrates the aim of strengthening corporate governance rather than reporting on gender diversity standards according to regulations.

\subsection{Gender Diversity and its Impact on Companies Performance}

Strong environmental, social and financial performance firms are the businesses that are diverse in the boardroom and workers.

It may be difficult to figure out if diversity results in good performance, even in Norway. Corporate world naturally is interested in is the effect of the financial performances of the companies. Financial performance is not just a single thing that shows the impact it's not a simple indicator. As with corporate law and CG debate, business activity must be distinguished from a company's actual economic results.

Even more complex impact is the social and environmental performance of the company. Their interrelated performances have even more complex impact. The effect can be related to long-term financial success while being highly socially relevant. Introducing gender diversity in corporate boards help firms in over-reaching societal goals of development, It's difficult to quantify, but a key topic to address, nonetheless.

Norwegian initiative however has motivated many other companies in different areas of the world, and they've put forward the gender diversity on boards issue by getting inspired by the Norwegian initiative. Several countries propose 
similar legislation or at least suggest it. General examples contain Sweden back in 2003, Spain in 2008 and Germany most recently.

\subsection{Effect of Rule on the Composition of Boards}

As the one result of Norwegian rule contributed in more women representation in their boards and women managers in public firms was more than ever. Women managers replaced men. There are not as many directors as possible according to law so by this it is compulsory to appoint necessary number of token female directors.

The word of mouth of lawyers of companies who had to rule first with the effect of the rule brought the best women into and pushed out some of the less qualified men. A Danish journal has published that Norwegian boards have removed less skilled, highly motived men as the direct consequences of section 6-11a and set them aside with top trained, highly interested females.

A further result of this legislation is that Danish women are recruited to some Norwegian boards and thus Nordic representation is increased in the administrative bodies of public corporations in Norway.

Cultural diversity has grown rapidly and resulting needs to look outside traditional circles to find out the most capable directors. Research has shown that the age diversity is also slightly changing. Social and ethnic diversity will increase very soon. Women managers are more qualified than the men.

When selecting is based not on social status and connections but on education and formal qualifications then there possibly will more chance for more qualified people.

\subsection{Effect of Rule on Registration of Public Companies}

When the Norwegian rule was introduced, it was pointed out that the limitation on public corporations of the application of section 6-11a could affect business organisation.

Section 6-11a played a major role when Norwegian corporate group Aker was formed into a corporate structure. The article said that this segment has resulted in the organisational decision to organise the parent company as a privatelyowned business in order to avoid legislation of gender diversity.

More specifically, the transition from public to private companies of companies and new public enterprise registrations was expected. The number of percentages of public corporations' registration in Norway has decreased by more than 50 percent. This is because of gender diversity quota seems somehow immediate. A study of 108 of the 126 reregistered companies for 2007 and 2008 revealed that, due to other factors, most companies were re-registered. Only a very few re-registrations are directly could be accredited to gender quota rule.

The question whether gender quota rule is a discouragement for companies registering after 2008 to select a public company form is an open one. The laws on gender equity are so agreed as to not even prejudice the registration of a public firm today by employee-elect directors.

The rule itself is fine, and only few company decision makers respond negatively to the percentage of decreases in the number of public companies.

A degree of regulatory competition is inevitable in our globalised era, where companies not only select the type of organisation they adopt, but also their country of registration.

\subsection{Interrelated Effect of Rule on Environmental, Social and Financial Performance of Corporations}

The effect of gender diversity on the wider society of companies is important to numerous and specific characteristics that women carry into the formerly male domain. Based on survey of Swedish directors and CEO's by Renee Adam and Patricia Funk showed that women are more benevolent, less power-oriented and more universally concerned than men. This make it special relevant in discussion because of the Norway and Sweden are socially relatively alike. In a wider social sense, gender diversity on the board is a strong indication is showed by a Dutch study by Mijntje Lückerath-Rovers.

The Matsa and Miller research showed that Norwegian companies' short-term profit is lower, as labour costs are increasing relatively. It poses concerns if it would foster the long-term and wider vision in terms of value-making 
inside companies to have more women in the boardroom. Other research carried out by the Richard Bernardi and Veronica Threadgill also show a potential link among women managers and more community focused board members.

The rise in gender balance in company is also possible as a major consequence of the quota rule. Early reports showed a rise in the number of females in companies as a result of female's increasing visibility following the legislative change. Gender quota is currently being criticised for not expanding the diversity of gender in the organisation enough. This indicates that the strongest opposition to the Norwegian gender quota has been diminished.

\section{Pakistan Code of Corporate Governance}

Securities and Exchange Commission of Pakistan (SECP) introduced the concept of corporate governance in Pakistan in 2002, but the literary contribution in governance mechanisms is still very limited. Mechanisms for corporate governance and firm performance were always a subject of discussion for believer's stewardship theory and agency theory.

Agency theory argues that the company often operates on condition of instability and lack of knowledge. This theory also states that separation of ownership from control communicates that professionals manage the business. Classified access to information to experienced managers offers an added personal advantage, since managers are more likely to support themselves than shareholders. The stewardship theory is also known as stakeholder theory, which indicates that managers are generally trustworthy and do not indulge in inappropriate decision making. After thorough review and selection, the agents should have our faith that they would act in the organisation's best interests. The stewardship theory concerns primarily managerial behaviour; after finalising the job in time and efficiently, it assumes the primary motivation factor for managers is satisfied. The managers therefore conduct pro-organizationally and according to the mission and objectives.

In Pakistan Corporate entities are primarily regulated under the Banking Companies Ordinance 1962, Companies Ordinance 1984, SECP Act, 1997, Securities and Exchange Ordinance, 1969, Insurance Ordinance 2000 and the various rules and regulations made there under.

A major step forward in the reform of corporate governance in Pakistan was the establishment of the Pakistan Corporate Governance Code (CCG) in March 2002 by SECP to establish a good governance framework for PSX companies. In April 2003, SECP released two reports on the harmonization of CCG with the other legislations in Pakistan and on the effect evaluation of Code in September 2003; CCG was soon followed by these to reports. In 2005, the World Bank conducted a Review of Observance of Standards and Codes (ROSC), in accordance with its recommended procedure. The survey of the Effectiveness of Boards in Pakistan was completed in 2006 with a pioneering effort by Mr. Zaffar A Khan in his personal capacity in addition to the KSE survey on CG in the same year and with the funding of the International Finance Corporation (IFC) a further survey was issued in November 2007 on Corporate Governance Practices in Pakistan.

The existing Code is a collection of the best practices, partly as "based on principles" and partly as "based on code" in order to provide guidance for PSX listed companies with the goal of safeguarding stakeholders' interests and developing market trust.

\subsection{Implementation of the Pakistan Code of Corporate Governance}

The Code is a complete document that sets the guidelines and rules for improved management and, by implementing it in the listing rules and regulations; it applies to all listed companies. Furthermore, as part of its prudential regulation of bank companies, the State Bank of Pakistan (SBP), which regulates banks in Pakistan, has implemented Guidelines of Corporate Governance. These guidelines are more stringent than in the Code itself, in respect of governance practices. Subsequently, a separate guideline has been provided by SECP governing non-banking finance companies to allow such corporations to obey the Code.

It was noted that, in view of best governance practices worldwide, the Code needed to correct any lacuna or gaps that might exist and that this was not addressed as a result of the voluntary existence of respect for most of the principles defined in the Corporate Governance Code. Moreover, because the shareholder structure of the listed undertakings was primarily controlled, whether by the family, multinationals or by the public, through single majority groups, with limited distribution or a large share base. The saving grace was the collective voting scheme for managers that were presented at the time of the Company Ordinance 1984. 
Pakistan Institute of Corporate Governance (PICG) was established as a public-private partnership in 2004 with Securities and Exchange Commission of Pakistan, playing a vital role in combining State Bank of Pakistan with seventeen other CG associations. Today, PICG is a hybrid Institute of Directors and Institute of Governance. As Institute of Directors, it establishes professionalism and inspires the participation of companies and organizations in the role of successful supervision and as the Institute of Governance; it raises awareness and promotes practices of good governance. It is unique in the IFC Middle East and North Africa Region and has been acknowledged as a story of success for other nations in the region to emulate.

Pakistan Institute of Corporate Governance, by enhancing the standard of CG in Pakistan, is a leading knowledge provider for all key stakeholders affected by CG. In November 2006, SECP requested that the Code be reviewed by IFC. In this process, SECP would provide transparency, guidance and coordination. IFC therefore recommended that the PICG carry out the mission since it was better equipped to promote good governance in Pakistan and was already in the process. In the PICG Board where both SECP and SBP were represented the matter was addressed. Moreover, the then Chairman of the SECP was the elected Chairman of the PICG Board.

\subsection{Gender Diversity in the Corporate Boards of Pakistan}

\subsubsection{Women on Board}

In 2017, SECP released the revised CCG under the new Companies Act 2017, requiring at least one female director on the board of all public listed companies, and providing one female executive with training every year under the Directors Training Program.

The goal is to increase the number of female directors in three years from 6.4 percent to 12.8 percent. At present 69 out of 100 companies have no female director, including 16 of the 20 largest listed companies, as stated in the KSE 100 of PSX? The percentage of female directors in listed companies is just 6.4 percent. It is also much smaller than the percentage of female directors in S\&P 500 and FTSE 100 firms, which now range from 20 percent to 25 percent.

52 percent of Pakistan's population is female, but it is quite marginal to bring females on board. WOB conducted research in 2017 on 505 companies listed on the PSX, finding that the overall number of female directors is 9.07 percent, although only 0.83 percent of the female directors are non-related or occupational. The remaining 8.25 percent are women directors linked to the family.

Since the beginning of the Director Certification Program in 2007, only 162 women have been certified from the Program by the PICG. 73 of these eligible women are BODs of the listed companies.

The new Pakistan Survey 2020 by WOB, released during the PSX ceremony 'Ring the Bell for Gender Diversity,' shows some change over the past four years. This survey is contained in WOB Pakistan, a global initiative aimed at making diversity a key component of corporate success. WOBs plan to have a minimum gender equality of 25 percent on Pakistan's corporate boards by 2025.

\subsubsection{Appointment of Women on Board}

Family relations are the main criteria for appointing women to boards. There is a belief that gender diversity will benefit if Pakistan's leading companies agree that gender diversity is the best corporate governance practise and tap into their broader pools of knowledge, innovation, talent, and expertise. This will also encourage families to open their boards to independent professional expertise and judgements and open the way for skills and experiences instead of parenthood to become the main criterion of their boards' appointment.

\subsubsection{The Perceived Benefits of Gender Diversity}

Women in board's perceived benefits include the perception that woman relatives defend business interests, woman's success and the need for informed decisions. Since the real advantages of gender-based boards, such as improved financial efficiency, inclusive decision making and consumer segmentation are not properly evaluated, the possible business case for gender diversity in Pakistan has not been completely addressed.

\subsubsection{The Challenges of Gender Diversity}

The main challenges for qualified and experienced women on boards are their perception that they do not have business skilled, that is, a sense of entrepreneurship and complexity, that they cannot achieve a balance between work 
and life, that they are actively influenced by emotion, that qualified and experienced women are not available and, thus, that women have a risk-negative nature. Survey companies perceived that women with the right qualities, ability and attitude would face these massive challenges and would eventually become board members. This development would be assisted by policies and procedures on work-life balance, which could accelerate their ascent to board positions.

\subsubsection{The Outlook of Gender Diversity}

The survey companies expect that the boards of directors will be reached by women on their own merit by demonstrating attitude and ability, so that changes in thinking and behaviour can make the advancement of women from middle management to executive roles. In order to turn gender diversity into common practise, Pakistan's leading corporations should take the lead by understanding and welcoming the business case for gender diversity from top to bottom. It leads to case studies which can be used as a foundation for a business case in which professional and qualified women are represented on boards which other organisations may support.

\subsection{Implementation of Gender Diversity in Pakistani Corporate Boards}

For every 50 biggest top performing companies in Pakistan, 7 are still not represented by women in the boardrooms. Women, especially in boardrooms, are underrepresented on nearly every corporate ladder. Companies with gender diverse boards, just a few have more than one female director. Most of them are appointed independent directors in the last few years. Such companies' boards vary from seven to fifteen, but they only have one to two or no female directors on their boards.

Companies like Fauji Fertilizer Company Limited (FFC), Archroma Pakistan Limited (ARPL), Al-Ghazi Tractors Limited (AGTL), Dawood Hercules Corporation Limited (DH Corp), Unilever Pakistan Food Limited (UPFL) have only one female director on their board. Only Biafo Industries Limited Company has four female directors in their board. Many companies like International Industries Limited (IIL), Pakistan Oilfields Limited (POL), ICI Pakistan Limited, and Attock Petroleum Limited (APL) still don't have any female director in their board.

\subsection{Steps Taken by the Companies towards Gender Parity}

International Women's Day was marked in accordance with joining 80 stock exchanges across the world by PSX. From the different sectors of the economy, 18 top leading Pakistani women professionals rang the bell to open the trading day in the celebration of International Women's Day at the Stock Exchange. This event was collectively organized by WOB, IFC, PSX and the Pakistan Business Council (PBC). In this event and bell ringing ceremony there were speeches, panel discussions and giving of mementos to these women professionals of the Country for the awareness of board gender diversity.

Diversity and Inclusion (D\&I) Conference 2020 gives the opportunity to better understanding, so companies can compete effectively in the market, the mechanism of progressive transformation from dealing diversity as a matter of legal and ethical compliance to positioning it as a strategic asset. Dialogue with the speakers is a great opportunity to understand the business with diversity and business sustainability from social and financial indicators that have impact through this. It also enhances the expertise in working through diversity and strategic and action plans to upgrade the organizations performance.

Chartered Financial Analyst (CFA) society Pakistan awarded National Foods Limited by label of Gender diversity. The main purpose of this award was to appreciate on basis of female employees' proportion at all management levels and even on BODs. Great compensations were given to females and the Board consisting of seven directors had two female directors.

Nestlé Pakistan is considered in one of those progressive organizations at Global Diversity and Inclusion Benchmarks (GDIB) awards in 2020. Nestlé Pakistan has best practice awards as in vision, leadership and structure because of diversity and inclusion within the organization. Their Board consisting of ten members have one female and, they have given females the managerial positions. Towards the Gender parity the step taken by Nestle Pakistan is remarkable as they are working on increasing more female proportion in organization by 20 percent to 30 percent by giving senior executive positions through their Gender Balance Acceleration Plan by the end of 2022.

Unilever is on a mission to enhance gender equality within the organization and now 50 percent of their managerial roles in the organization are under the control of female employees in accordance of making company's positive 
progress. This 50 percent division delivers the progress of the goal that has set back by them in 2010 when 38 percent of the roles were in hands of females. By that time the company have introduced many programmes and series in the favour of women to break down any barriers in recruitment. Unilever want to be famous of their D\&I. By this they mean to deliver a message of progress in accordance with equality and opportunities they've given to the females to show their competence and helping them unlocking their full potential in professional ways and by showing that company is fair and attracting.

In Habib Bank Limited, development goals adopted in September 2015 by the National assembly which emphasis on the women empowerment in accordance to achieve gender equality and diversity including economic empowerment. Bank worked on encouraging changing within for progressing gender diversity throughout the company. Their Board consist of eight directors have one female as well and they've launched NISA banking for encouraging females' inclusion by 5 percent to 25 percent and Women force in 2017 was 15 percent. New roles were assigned to females up to 50 percent within banking sector. Bank is now working more on enhancing female employees force to 20 percent by 2020 .

\subsection{Gender Diversity Gap in Pakistan}

The World Economic Forum (WEF) ranked Pakistan as third last in economic participation as well as women role and opportunities. Participation of female workers is as low as 24 percent and their even low participation and representation in the Pakistani boardroom. Top firms of Pakistan are still male dominating.

In 2017, Pakistan is ranked as 143rd on the WEF index because of low economy and lowest ranked country in the South Asia. This index reportedly measures the gender gap in four areas including economic participation, health and survival, educational attainment and political empowerment. While in 2018, Pakistan is ranked on 148 of 149 countries on WEF, Pakistan have no proper record of gender diversity.

For building more economies dynamic and inclusive it must be ensuring that everyone has equal opportunities. When women are not indulged in firms less benefits are seen, and communities loses out of skills and ideas. By this it is difficult for the challenges and new opportunities.

Globally the case of indulging more diversity in the boardroom is being established. Some researchers have established correlation between the diversity and corporate outperformance. Gender equality in corporate boards are establishing while Pakistan failed to keep pace.

CCG implemented under the companies act, 2017 requires all the companies to induct at least one woman on the stock exchange or others' the number of employees' turnover' and the number of shareholders. The 2019 code based on a "Comply or explain" approach that indicated certain subjects as mandatory. Hence it is mandatory for every board to have at least one woman in their workforce.

WEF shows that Pakistan must do a lot more progress in indulging women as to benefit and shape the economy. Pakistan must take more initiatives in boardrooms in order to closing gender gaps and to make them more inclusive and diverse.

Women in Pakistan are underrepresented on most levels especially in senior management positions as well as in boardrooms.

The issue of diversity is still on its peak and most notable new companies act indicated at least one position for woman director in every public interest companies on the board. However still women position in the boards require more work and detailed debates just 11 percent representation is not enough for 1000 plus public interest companies.

Just hiring of women where diversity maybe more prominent should not be the case they should have given the chance in all senior management positions for showing their competence and equality in all fields.

\section{Recommendations}

1. Organizations should work on gender diversity in their planning and to adopt corporate governance policy. Like Malaysia and India, directors training programs should be enhanced in Pakistan by arranging trainings for female directors so that they could enhance their skills in the respective field to compete with male directors in male dominating boardrooms. 
2. In Pakistan there should be initially minimum of 10 percent quota and some incentives for the firms like Spain that by choice doubles this quota for their boards so that women could be seen progressing in such way by showing their competency. It is a time to fight for more women empowerment and against just male dominancy all over the boards.

3. Women should be welcomed and respected in corporate boards for the value and reputation that they bring in corporations by their skill full work and competence. In Pakistan the manner of respect should be given highly because of women the value that they get in their decision making in boards like Peru. Women should be welcomed and given equal and utmost respect in the firms.

4. There should be no discrimination in the boardrooms like New Zealand and board should be completely discrimination free in Pakistan. Many women face discrimination because of male dominancy in the boardrooms, it becomes harder for women to perform their work efficiently. Discrimination free environment could be so much progressing for the corporations as team can do wonders together.

5. The Code of Corporate Governance should be updated to require companies to reveal their diversity policies to achieve their goals and progress is made like Singapore and Australia. It suggests that unless progress is made, the need for stronger regulatory action could be considered.

\section{Conclusion}

With a high level of equal rights for women and a high proportion of women at work, Norway is one of the most equitable nations in the world. In order to change the composition of the boards, however, obligatory rules were necessary. Norway was the world's first country to appoint gender diversity in the board of directors and Norway's innovative gender-based legislative approach. Companies are important to corporate governance in terms of gender diversity, and gender diversity affects the performance of companies.

This has a broader impact on the board of directors of gender diversity, including the urgent issue of whether gender equality in the corporate boards can aid businesses lead sustainable development across the world. The review of Pakistan's gender diversity in corporate boards and legislative measures has been presented in this research. Unfortunately, in Pakistan corporate boards have not enough legislation on gender diversity like Norway and other countries. It was initiated and regulated in Pakistan by the Corporate Governance Code, Companies Act and the Securities and Exchange Commission of Pakistan to bring about gender diversity in corporate boards. This research also made some recommendations for the board gender diversity in Pakistan.

\section{References}

Aqil Waqar Khan and Qazi Abdul Subhan, "Impact of Board Diversity and Audit on Firm Performance," Cogent Business \& Management 6, no. 1 (June 2019).

Aftenposten, “Report from Norway, Han Skaffet 800 Styrekvinner,” February 4, 2008.

Beate Elstad and Gro Ladegard, "Women on Corporate Boards: Key Influencers or Tokens?," Journal of Management \&amp; Governance 16, no. 4 (2010): 595-615.

Beate Sjjfjell, "Gender Diversity in the Board Room \& Its Impacts: Is the Example of Norway a Way Forward?," Deakin Law Review, 2 no.1 (2015): 25-52.

Chris Bryant, "Germany backs quotas for women on boards," Financial Times, November 26, 2014.

"Danish women are exported to Norway," E24, April 20, 2008.

Deutsche Welle, "Inequality Still Presides for Women in German Boardrooms," October 9, 2014.

"Germany Agrees Law on Quotas for Women on Company Boards," BBC News (BBC, November 26, 2014).

Karl Valentini, "Gender Diversity in Boardrooms: Trends And Assumptions Along The Path To The Boardroom," Scholarly Commons, 2017. 
Leslie Crawford, “Feminist," Financial Times, April 16, 2008.

Marianne Bertrand et al., "Breaking the Glass Ceiling? The Effect of Board Quotas on Female Labor Market Outcomes in Norway.," SSRN Electronic Journal, 2014.

More Women on Norwegian Boards — Bad or Good?, Magma, 2011.

Norwegian Public Limited Liability Companies Act 1997

Norwegian Register of Business Enterprises Act 1985

Richard A. Bernardi and Veronica H. Threadgill, "Women Directors and Corporate Social Responsibility,” SSRN, January 31, 2011.

Robert Anderson, "Norway Rushes in Female Directors," Financial Times, December 31, 2007.

“Sweden’s Glass Ceiling Begins to Crack," Financial Times, May 12, 2003.

Tineke Lambooy, "Legal Aspects of Corporate Social Responsibility," Utrecht Journal of International and European Law 30, no. 78 (2014): pp. 1-6.

Vibeke Heidenreich, "Consequences of the Norwegian Gender Quota Regulation for Public Limited Company Boards," Getting Women on to Corporate Boards, (2013): 119-125. 